\title{
Community Analysis and Perception of the Development of Kuri Beach Tourism Area in Maros Regency
}

\author{
Irmawanty*, Dian Safitri \\ Biology Education Study Program,Faculty of Teacher Training and Educational Sciences, Universitas \\ Muhammadiyah Makassar, Indonesia
}

*Corresponding Author: Irmawanty, Biology Education Study Program,Faculty of Teacher Training and Educational Sciences, Universitas Muhammadiyah Makassar, Indonesia

\begin{abstract}
This study aims to (1) identify Kuri Beach marine resources that can support the development of marine tourism objects (2) find out public perceptions of tourism development efforts at Kuri Beach and the relationship of livelihood factors on these perceptions (3) to find out the development of the appropriate Kuri Beach area with its biophysical characteristics. This research is descriptive qualitative research, describing the potential of marine resources of Kuri Beach, which is the supporting factor of its development. This study involves chi-square analysis to find out public perceptions of their support on the development of this area. The result shows that in terms of regional biophysics, Kuri Beach was developed as a tourist area. The sociocultural and economic conditions of the local community support this development. But to realize this expectation, there are still some obstacles faced, namely, the large supply of sediment from Maros River that enters the coast, the low level of accessibility and the high content of total suspended solids (TSS) in the rainy season. All these obstacles must be considered and a solution is sought so that the wishes of the Maros Regional Government to develop its coastal area can be realized.
\end{abstract}

Keywords: Public Perception, Tourist Area, Kuri Beach, Nautical

\section{INTRODUCTION}

Indonesia's marine potential is very large and diverse. This potential is reflected by a large amount of biodiversity, in addition, to the potential of coastal aquaculture in the sea and marine tourism. Indonesia's marine and coastal areas have turned out to have amazing natural resources. This requires a moral commitment to maintain, preserve and utilize these resources in a sustainable manner (Dahuri, 1996).

Many coastal areas in Indonesia have experienced increasingly severe and complex ecological pressures, both in the form of pollution, over-exploitation of natural resources and erosion of biodiversity, physical degradation of coastal habitats, and conflicts over the use of space and resources. Some coastal areas of the level of ecological damage have reached or exceeded the carrying capacity of the environment, the sustainable capacity of the ecosystem of the region to sustainable development activities and human life in the future. Indonesia still relies on conventional tourism that utilizes biological natural resources and its ecosystem (Ramdan \& Ihkwana, 2016).

The increase of Indonesia's population and the fact that resources on land are depleting, the coastal and oceanic regions and all natural resources and environmental services contained in them are expected to become the foundation of 21st-century national development (Dahuri, 1998). The potential of marine resources should be exploited as optimally as possible in advancing marine tourism, without neglecting the aspects of environmental/marine and coastal ecosystems.

Sunarto (2000) mentioned that the magnitude of the potential and beauty of Indonesian marine parks are also recognized by a number of international marine tourism lovers. Marine tourism has unique characteristics compared to other types of tourism. Besides being generally used as a hobby that can encourage tourists to visit again, the expenditure of marine tourists is generally greater than other tourists. Thus, marine tourism has great potential to increase the inland revenues. So, we need to develop the strategy in order to make all tourists stand for a long time. One way to develop tourism businesses is improving service facilities for tourism activities. This is based on development 
programs and policy activities that are integrated and cannot be separated from the development patterns of other sectors. Success in developing tourism is also largely determined by the ability to manage and utilize all the potential of existing tourism.

South Sulawesi Province is one of the provinces in Eastern Indonesia that has a wealth of potential marine natural resources. The main advantages of this region are its very strategic location, diversity of marine life, culture and human resources, coastal and marine industries and economic diversification. This area is very suitable for the development of marine tourism to complement the existing development on the mainland.

One of the districts in South Sulawesi that has a considerable tourism development potential is Maros Regency. This potential rests on the natural beauty of mountains and beach. In addition, this tourism potential is spread throughout almost all districts. There are various types that has a high potential to be developed, such as diverse, both in the form of marine tourism, nature tourism, and cultural tourism. However, the tourism potential is not yet been maximally developed. Also, there is still no link among tourism potential, though it has a lot of tourism potential (Rizkiyani \&Suprihardjo, 2013).

The existence of tourist areas in coastal areas strongly supports the object of regional development. This is related to the development of coastal tourism objects. Beach tourism objects in Maros Regency include Kuri Beach and Pute River Batu Napara (Binanga Sangkara estuary). Kuri Beach is an area that will be developed as a marine tourism object. The distance to the location of this tourist attraction is $20 \mathrm{~km}$ west from Maros city, and approximately $18 \mathrm{~km}$ from Makassar city. For this reason, it is necessary to conduct studies or research on the potential of existing resources on this beach that can support the development of marine tourism areas in the location. The results of the study will be expected to contribute the region in general and the local community in particular.

\section{METHODS}

This research is a qualitative descriptive study that aims to describe the potential and public perception of Kuri Beach marine resources that can support the development of marine tourism. To find out the public perception about their support for the development of marine tourism areas chisquare analysis was used. The population of this study is that all residents living in Nisombalia Village are measured based on the number of Family Heads (KK). Overall, the number of family heads $(\mathrm{KK})$ in four hamlets is 688 households. The research sample was taken from the population based on the Yamane formula quoted by Rachmat (1985). In this case, the number of population $(\mathrm{N})$ is 688 household heads (KK). The degree of freedom set at $10 \%$ with a trust level of $90 \%$. Thus the number of 87 families is obtained.

Data collection techniques consist of 4 stages, namely: Observation, which is a technique carried out by observing each marine resource, both on the surface and inside / the seabed on the coast. Water quality measurements carried out by taking water samples are then analyzed in the laboratory, structured interviews namely asking a number of questions in the form of questionnaires, and documentation, namely collecting various data and documentation or related material related to this research or data from research results this. The data obtained are then analyzed descriptively and the conclusions are based on percentages (Sevilla, 1993).

\section{RESULTS AND DiSCUSSION}

\subsection{Sea Water Quality Standard}

Observations on water quality physically, chemically, and biologically carried out at six stations are presented in Table 1.

The results of water quality measurements will be compared with seawater quality standards to find out whether they meet the standards or not for an allocation. What is intended to meet seawater quality standards is if the value or level of parameters for measured seawater is within the boundary or in accordance with the provisions of seawater quality standards determined based on the Governor's Decree of the Head of South Sulawesi Number 465 of 1995 (Regional Bappeda III Edge Pandang, 1995)?

The results of measurements of seawater quality in Kuri Beach, Maros Regency can be seen in the following Table. 
Table1. Observation Results of Water Quality for Each Observation Station

\begin{tabular}{|l|l|l|l|l|l|l|}
\hline \multirow{2}{*}{ Parameter } & \multicolumn{9}{c|}{ Station } \\
\cline { 2 - 8 } & \multicolumn{1}{|c|}{$\mathbf{1}$} & \multicolumn{1}{c|}{$\mathbf{2}$} & \multicolumn{1}{c|}{$\mathbf{3}$} & \multicolumn{1}{c|}{$\mathbf{5}$} & \multicolumn{1}{|c|}{$\mathbf{5}$} \\
\hline Physics Smell & Natural & Natural & Natural & Natural & Natural & Natural \\
\hline Floating Objects & Nil & Nil & Nil & Nil & Nil & Nil \\
\hline Amount of solids & 334 & 322 & 80 & 249 & 199 & 123 \\
\hline Suspended (TSS) ppm & & & & & & \\
\hline Brightness (m) & 1 & 0.78 & 0.90 & 0.15 & 0.50 & 0.30 \\
\hline Turbidity (NTU) & 11.34 & 7.93 & 6.89 & 15.6 & 18.9 & 23.7 \\
\hline Oil layer & Nil & Nil & Nil & Nil & Nil & Nil \\
\hline Temperature $\left({ }^{\circ} \mathrm{C}\right)$ & 32 & 33 & 31 & 32 & 32 & 32 \\
\hline Color $($ TCU) & 47.2 & 54.8 & 49.0 & 56.3 & 51.4 & 45.2 \\
\hline CHEMISTRY pH & 7.36 & 7.20 & 7.40 & 7.47 & 7.32 & 7.13 \\
\hline Salinity $\left(00 /{ }_{0}\right)$ & 34 & 35 & 35 & 35 & 34 & 34 \\
\hline Dissolved oxygen(DO) ppm & 6.12 & 6.32 & 7.68 & 6.95 & 7.15 & 6.32 \\
\hline BOD (ppm) & 1.71 & 1.41 & 2.03 & 1.25 & 1.60 & 1.32 \\
\hline BIOLOGY E Caliform APM/ml & - & - & 9 & 4 & - & - \\
\hline Pathogen (E. Coli) sel/100 ml & Nil & Nil & Nil & Nil & Nil & Nil \\
\hline
\end{tabular}

From the results of measurements of water quality after being compared with seawater quality standards, it was stated that the waters of Kuri Beach did not have the potential to be developed as a marine tourism object for bathing and swimming purposes. This is caused by low brightness and high amount of suspended solids (TSS).

The total suspended solids content (TSS) measured in the waters of Kuri Beach is quite high, which is around 123 - $334 \mathrm{ppm}$. Whereas, the waters in a value of suspended solids of $300-400 \mathrm{ppm}$ have badly pushed quality (Allert, 1984). Based on the water quality standard, the TSS content in Kuri Beach waters is high because it is far above the desired threshold of $23 \mathrm{ppm}$. Such water conditions are not suitable for bathing and swimming purposes because the water quality is cloudy and makes the eyes sore.

\subsection{Community Perception of Marine Tourism Development in Kuri Beach}

In developing coastal and coastal areas for allocation, in addition to assessing the biophysical potential of the region, community participation is also very important. The involvement of local people who have usage rights (Common property) will determine the success of the development. This was also done in the effort to develop Kuri Beach marine tourism. Community perception is one of the variables studied to measure the feasibility of developing a marine tourism area in Kuri Beach. From this perception, it will be seen where the local community supports or rejects the presence of marine tourism activities in the region. Measurement of public perception is divided into sociocultural and socio-economic perceptions.

\subsection{Perception of Socio-Culture}

The socio-cultural components studied were (1) people's understanding of the concept of tourism, (2) community support for the development of Kuri Beach as a marine tourism area, (3) social attitudes towards the presence of outsiders, and (4) religious life of the local community.

The results of the research through the distribution of questionnaires to the above components will be distributed in the following Table.

Table2. Perception of Respondents' Understanding of the Concept of Tourism

\begin{tabular}{|l|l|l|l|}
\hline \multicolumn{1}{|c|}{ No. } & \multicolumn{1}{|c|}{ Perception } & \multicolumn{1}{c|}{ Number of Respondents } & \multicolumn{1}{c|}{ Percentage (\%) } \\
\hline 1 & Understand & 60 & 69 \\
\hline 2 & Doubtful & 16 & 18 \\
\hline 3 & Do not understand & 11 & 13 \\
\hline Total & 87 & 100 \\
\hline
\end{tabular}

From table 2 it can be seen that respondents' understanding of the concept of tourism varied, 60 people (69\%) understood tourism activities, 16 people (18\%) were hesitant and 11 people (13\%) did not understand what tourism was. 
Furthermore, the distribution of respondents according to their perceptions of the development of Kuri Beach as a tourist area is presented in the following Table.

Table3. Perception of Respondent's Support for Kuri Beach Development as a Marine Tourism Area

\begin{tabular}{|l|l|l|l|}
\hline \multicolumn{1}{|c|}{ No. } & \multicolumn{1}{|c|}{ Perception } & \multicolumn{1}{c|}{ Number of Respondents } & \multicolumn{1}{c|}{ Percentage (\%) } \\
\hline 1 & Support & 47 & 54 \\
\hline 2 & Doubtful & 35 & 40 \\
\hline 3 & Does not support & 5 & 6 \\
\hline Total & 87 & 100 \\
\hline
\end{tabular}

Table 3 shows that respondents who supported the development of Kuri Beach as a marine tourism area had 47 people or around 54\%, who doubted 35 people or $40 \%$ and did not support 5 or $6 \%$.

For the social attitudes of the community towards their openness, accepting the presence of outsiders will be presented in Table 4 .

Table4. Respondents 'Perceptions of Openness They Receive Outsiders' Presence.

\begin{tabular}{|l|l|l|l|}
\hline \multicolumn{1}{|c|}{ No. } & \multicolumn{1}{|c|}{ Perception } & Number of Respondents & \multicolumn{1}{c|}{ Percentage (\%) } \\
\hline 1 & Support & 32 & 37 \\
\hline 2 & Doubtful & 30 & 34 \\
\hline 3 & Does not support & 25 & 29 \\
\hline Total & & 87 & 100 \\
\hline
\end{tabular}

Table 4 shows there are 32 people or $37 \%$ who can accept the presence of outsiders to travel in their area, 30 people or $34 \%$ feel they are still in doubt and 25 people or $29 \%$ who cannot accept the presence of outsiders to travel in their area.

From religious life, it is known that the population of Muslims in Nisombalia Village reaches 99\% and those who are $1 \%$ Protestant Christians. Here is a table that shows the community's perception of the religious life of the local community.

Table5. Respondents' Perception of the Religious Life of the Nisombalia Village Community

\begin{tabular}{|l|l|l|l|}
\hline No. & Perception & Number of Respondents & Percentage (\%) \\
\hline 1 & Support & 43 & 49 \\
\hline 2 & Doubtful & 20 & 23 \\
\hline 3 & Does not support & 24 & 28 \\
\hline Total & 87 & 100 \\
\hline
\end{tabular}

Most of the respondents, 43 people (49\%) thought that the Nisombalia Village community had a religious life, the remaining 20 people (23\%) were hesitant and 24 people $(28 \%)$ stated no.

In general, the local community is Muslim and adheres to the "Khalwatiyah Muhammad Sammang" school. In each year a ritual of diversity is held, namely the celebration of the Birthday of the Prophet on a large scale.

\subsection{Perception of Socio-Economy}

The socio-economic aspect is one of the factors that support the development of marine tourism activities on the Kuri coast.

The socio-economic aspect of the community that is seen is the type of livelihood of the local community. What needs to be analyzed here is the relationship between community livelihoods and their support for the development of Kuri Beach as a marine tourism area.

The following is a table of the distribution of respondents according to their type of livelihood.

Table6. Distribution of Respondents by Livelihood Type

\begin{tabular}{|l|l|l|l|}
\hline No & Livelihood & Number of Respondents & Percentage (\%) \\
\hline 1. & Fisherman & 61 & 70 \\
\hline 2. & Farmer & 15 & 17 \\
\hline 3. & Traders & 6 & 7 \\
\hline 4. & Factory employees & 5 & 6 \\
\hline Total & 87 & 100 & \\
\hline
\end{tabular}


Table 6 shows that the highest number of respondents were fishermen, namely 61 people (70\%) because most of them were livelihoods (70.3\%). It is better for farmers to be 15 people (17\%), traders 6 people $(7 \%)$ and factory employees 5 people $(6 \%)$.

The community lesion is known through the results of answers to ten questions that were submitted in the questionnaire. Each respondent's answers were scored according to several categories: score 3 for answers of respondents who answered "yes", score 2 for respondents who answered "doubtful" and score 1 for those who answered "no" the number of scores from ten questions each respondent was categorized into two, namely, 10-20 for the non-supportive category and 21-30 for support. The definition of the support category is that they support Kuri Beach marine tourism development efforts. From the results of calculations with Ch-Square $\left(x^{2}\right)$ obtained $x^{2}=11,046$ with a confidence level of $95 \%$ and the value of $x^{2}$ table $=3.84$ from degrees of freedom (df) 1 , this indicates that the value $x^{2}$ count is greater than the value of $x^{2}$ tables, which is $11,046>3,84$. This means that Ho is rejected and $\mathrm{H} 1$ is accepted, so it can be concluded that the community supports the efforts to develop Kuri Beach as a tourist area tour.

The community supports with the hope that the development of the coastal area means that there will be improvements in road infrastructure and the construction of docks. According to (Ramdan \& Ihkwana, 2016) to realize tourism development, it is expected to coordinate with various interested parties, particularly in providing facilities and facilities for the development of tourist areas, such as health facilities, electricity networks, transportation and land to be used. The sources of development funding can be obtained from 3 basic sources, namely from the government/public, private/private as well as a combination between the government and the private sector.

Livelihoods do not affect people's perceptions of the efforts to develop Kuri Beach as a tourist area. This can be seen in the crosstable of the respondents' types of livelihood relationships with their perceptions of regional development efforts.

Table7. Livelihoods of Respondents with Perceptions

\begin{tabular}{|c|c|c|c|c|c|}
\hline \multirow[t]{2}{*}{ No } & \multirow[t]{2}{*}{ Livelihood } & \multicolumn{2}{|c|}{ Number of Respondents } & \multirow[t]{2}{*}{ Total } & \multirow{2}{*}{$\begin{array}{c}\text { Percentage } \\
(\%)\end{array}$} \\
\hline & & Support & Does not support & & \\
\hline 1. & Fisherman & 42 & 19 & 61 & 70 \\
\hline 2. & Farmer & 10 & 5 & 15 & 17 \\
\hline 3. & Traders & 3 & 3 & 6 & 7 \\
\hline 4. & Factory employees & 4 & 1 & 5 & 6 \\
\hline \multicolumn{2}{|l|}{ Total } & 59 & 28 & 87 & 100 \\
\hline
\end{tabular}

If the public perception is related to the type of livelihood and using the contingency coefficient analysis tool then the Chi-Square value $\left(\mathrm{x}^{\wedge} 2\right)=1.252$ with a $95 \%$ confidence level and the value of $\mathrm{x}$ $\wedge 2$ table $=7.81$ from the free degree $(\mathrm{df}) 3$ This shows that the value of $\mathrm{x}^{\wedge} 2$ count is smaller than $\mathrm{x}^{\wedge}$ 2 table, which is $1.252<7.81$. This means that Ho is accepted and $\mathrm{H} 1$ is rejected. It can be concluded that there is no relationship between the type of livelihood and perception. When continued with the contingency coefficient, the coefficient value is 0.119 and the significance level is 0.741 . Therefore, it can be concluded that there is no relationship between perception and livelihood because the significance level does not meet the requirements, namely 0.741 (significant number above 0.05 ).

\section{CONCLUSION}

This study indicates that (1) Kuri Beach is worthy to be developed as a marine tourism area, (2) The measurements of seawater quality standards carried out in the rainy season, physically, chemically, and biologically are known that the waters of Kuri Beach do not meet the sea water quality standards developed for tourism designation and bathing and swimming recreation. This is because in the rainy season the total content of suspended solids (TSS) is very high so the sea water is very cloudy, (3) Community perceptions support the development of Kuri Beach as a tourist area and there is no relationship between types of livelihoods and community perceptions, and (4) Based on the data obtained, the development of the Kuri Coast area that suits its biophysical characteristics is a beach resort, outdoor sports, water skiing, sailboats, surfing, fishing and enjoying the panorama of flora and fauna of mangrove forests. 


\section{REFERENCES}

[1] Alert, G. 1984. Metoda Penelitian Air dan Usaha Nasional. Surabaya.

[2] Bappeda Wilayah III Ujung Pandang. 1995. Keputusan Gubernnur Kepala Daerah Tingkat I Sulawesi Selatan No 465 Tahun 1995 Tentang Baku Mutu Air dan Udara di Sulawesi Selatan. Biro Bina Lingkungan Hidup. Ujung Pandang.

[3] Dahuri, R. 1996. Pengelolaan Sumberdaya Wilayah Pesisir dan Lautan Secara Terpadu.Jakarta : PT. Pradnya Paramita.

[4] Dahuri, R. 1998. Research Needs to Support Integrated Management of Coastal and Ocean Resources. Jurnal Pesisir dan Lautan (1): 53-55.

[5] Rakhmat, J. 1985. Metode Penelitian Komunikasi. Bandung : Ramadja Karya.

[6] Ramdan, M.R \& Ihkwana, A. 2016. Feasibility Analysis of Tourism Development in Cimareme Village, Banyuresmi District, Garut. Jurnal Kalibrasi, 14(1), 101-110.

[7] Rizkiyani, H.A \& Suprihardjo, R. 2013. Development of Talang Siring Coastal Zone in Pamekasan Regency. Jurnal Teknik POMITS, 2(2), 215-220.

[8] Sevilla, C.G. 1993. Pengantar Metode Penelitian. Penerjemah Alimuddin Tuwu. Jakarta : UI Press.

[9] Sunarto. 2000. Kasualitas Pologenetik dan Ekuilibrium Dinamik sebagai Paradigma dalam Pengelolaan Ekosistem Pesisir. Prosiding Seminar Nasional. Yogyakarta.

\section{AUTHORS' BIOGRAPHY}

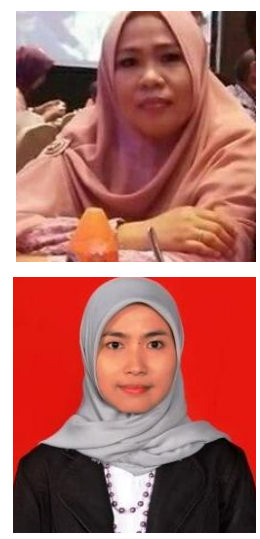

Irmawanty is currently teaching at the Biology Education Study Program, Faculty of Teacher Training and Educational Sciences of Universitas Muhammadiyah Makassar, Indonesia. Her research interests cover biology and biology education in general.

Dian Safitri is currently teaching at the Biology Education Study Program, Faculty of Teacher Training and Educational Sciences of Universitas Muhammadiyah Makassar, Indonesia. Her research traces various educational problems in universities, schools, and in the community. She is particularly interested in learning models implemented in the classroom.

Citation: Irmawanty, Dian Safitri. "Community Analysis and Perception of the Development of Kuri Beach Tourism Area in Maros Regency" International Journal of Humanities Social Sciences and Education (IJHSSE), vol 6, no. 2, 2019, pp. 29-34. doi: http://dx.doi.org/10.204 31/2349-0381.0602004.

Copyright: (c) 2019 Authors. This is an open-access article distributed under the terms of the Creative Commons Attribution License, which permits unrestricted use, distribution, and reproduction in any medium, provided the original author and source are credited. 